\title{
Redescription and systematic position of Soricinia tripartita Żarnowski, 1955 (Cestoda: Cyclophyllidea), a cestode species parasitic in shrews of the genus Sorex, including erection of Gulyaevilepis gen. $\mathrm{n}$.
}

\author{
Svetlana A. Kornienko ${ }^{1}$ and Rasa Binkiené ${ }^{2}$ \\ ${ }^{1}$ Institute of Systematics and Ecology of Animals, Siberian Branch, Russian Academy of Sciences, Novosibirsk, Russia; \\ ${ }^{2}$ Institute of Ecology, Nature Research Centre, Vilnius Lithuania
}

\begin{abstract}
Soricinia tripartita Żarnowski, 1955 is redescribed on the basis of specimens from the type host Sorex araneus Linnaeus from Lithuania, Latvia and Russia (Republic of Karelia and Republic of Komi - a new geographical record) as well as from Sorex satunini Ognev and Sorex volnuchini Ognev from Russia (Nalchik Area in the Caucasus Mountains). The strobilar morphology of S. tripartita is compared with that of other hymenolepidid cestodes of shrews with an unarmed scolex and serial development of proglottides in the strobila, i.e. species of Mathevolepis Spassky, 1948, Ditestolepis Soltys, 1952, Spasskylepis Schaldybin, 1964, Ecrinolepis Spassky et Karpenko, 1983 and Diorchilepis Lykova, Gulyaev, Melnikova et Karpenko, 2006. It was noted that S. tripartita does not correspond to any of the known genera. The following unique characters are found for S. tripartita: heteronomous serial strobilation with one or two sterile proglottides at the end of each series in the strobila and the whole copulatory part of the vagina covered with numerous, fine spines. Therefore, the new genus Gulyaevilepis is erected, with Gulyaevilepis tripartita (Żarnowski, $1955)$ comb. n. as its type and only species. Since the type material of Soricinia tripartita is not known to exist, a neotype from the same host species and from a locality close to the type locality is designated.
\end{abstract}

Keywords: morphology, taxonomy, Hymenolepididae, tapeworms, new genus, neotype, insectivores, Europe

Among the hymenolepidids (Cestoda: Cyclophyllidea) of shrews (Sorex Linnaeus), there is a group of species with an unarmed scolex and serial development of proglottides (Spassky 1954, Gulyaev 1991, Lykova et al. 2006). Currently, these cestodes are placed in the genera Mathevolepis Spassky, 1948, Ditestolepis Soltys, 1952, Spasskylepis Schaldybin, 1964, Ecrinolepis Spassky et Karpenko, 1983, and Diorchilepis Lykova, Gulyaev, Melnikova et Karpenko, 2006 (Gulyaev 1991, Lykova et al. 2006).

However, the generic status of Soricinia tripartita Żarnowski, 1955, which is frequently recorded in European shrews (Żarnowski 1955, Vaucher 1971, Genov 1984, Binkienè et al. 2011), still remains unclear. Żarnowski (1955) was the first to discover a new cestode species in Sorex araneus Linnaeus from the vicinities of Pulawy (Poland), which was placed in Soricinia Spassky et Spasskaya, 1954 as Soricinia tripartita. However, cestodes of the genus Soricinia have gradual strobilation and no vestige of the rostellar apparatus (Gulyaev 1991, Czaplinski and Vaucher 1994), whereas strobilation of S. tripartita is serial and there is a rudimental rostellum in the scolex.
Later, after several redescriptions, the cestode was placed in several genera, i.e. in Hymenolepis Weinland, 1858 by Rybicka (1959), Ecrinolepis by Gulyaev (1991) and Ditestolepis by Czaplinski and Vaucher (1994). In contrast to S. tripartita, species of Hymenolepis as well as those of Soricinia have gradual strobilation (Czaplinski and Vaucher 1994). Species of Ditestolepis and Ecrinolepis have serial strobilation, but the stobila of Ditestolepis consists only of hermaphroditic proglottides, and the stobila of Ecrinolepis consists of hermaphroditic and male proglottides (Gulyaev 1991). The strobila of S. tripartita has hermaphroditic and male proglottides, but each series ends with a sterile proglottis.

A phylogenetic analysis of hymenolepidid cestodes from rodents and shrews, using sequences of the partial $28 \mathrm{~S}$ ribosomal RNA gene, has shown that $S$. tripartita (reported as Ditestolepis tripartita) does not belong to the genera Soricinia or Hymenolepis, but within the Ditestolepis clade (Haukisalmi et al. 2010). According to these authors, all the four studied species of this clade [Ditestolepis diaphana (Cholodkowsky, 1906), Ditestolepis sp., D. tripartita and Spasskylepis ovaluteri Schaldybin, 
1964] may represent distinct genera because of their high genetic divergence.

The aim of the present study is to redescribe the species Soricinia tripartita and to determine its position among hymenolepidid cestodes parasitising shrews.

\section{MATERIALS AND METHODS}

Type specimens of Soricinia tripartita are not known to exist, and thus the present study is based on morphological examination of cestodes collected by the present authors from shrews Sorex araneus Linnaeus, S. satunini Ognev, S. volnuchini Ognev in Lithuania, Latvia and Russia (Caucasus, Republic of Karelia and Republic of Komi). Host specimens were dissected immediately after their death. Cestodes were isolated, washed and relaxed in water, and then fixed in $70 \%$ ethanol. Thereafter, they were stained with Ehrlich's haematoxylin, differentiated in $3 \%$ aqueous solution of ferric ammonium sulphate 12-hydrate and dehydrated in a graded ethanol series. The specimens were then cleared in clove oil and mounted in Canada balsam. Some specimens were mounted in Berlese's medium to facilitate examination of the copulatory apparatus (magnification $\times 1000$ ). The developmental stages of proglottides are defined using the terminology of Mas-Coma and Puchades (1991). Measurements are given in micrometres except where otherwise stated; they are presented as the range (min-max) followed by the mean and the number of the measurements (n) in parentheses.

The specimens included in the present study have been deposited in the Natural History Museum, Geneva (MNHG), the Laboratory of Parasitology of the Institute of Ecology of the Nature Research Centre, Lithuania (EKOI) and the Museum of Zoology of the Institute of Systematics and Ecology of Animals, Novosibirsk, Russia (ISEA).

\section{RESULTS}

\section{Gulyaevilepis gen. n.}

Diagnosis. Strobila small. Proglottides acraspedote, wider than long except gravid (longer than wide). Scolex rounded, without rostellar sac and rhynchus; rudimentary glandular sac-like rostellum. Suckers elongate, cup-shaped, inside of dorsal and ventral bothrium-like depressions of scolex. Strobilation serial; each series ends with one or two sterile proglottides. Metameria heteronomous. Osmoregulatory canals without transverse anastomoses. Three testes situated in triangle, two antiporally and one porally. Cirrus armed. Internal seminal vesicles absent. External seminal vesicles elongate. Cirrus-sac reach, or may slightly cross midline of proglottis. Vagina armed, not clearly differentiated from seminal receptacle. Ovary bean-shaped, compact or slightly bilobed. Vitellarium compact, situated in centre of proglottis. Uterus median, initial horseshoe-shaped uterus transforms into sacciform by reducing recess in posterior wall of uterus due to straightening of the wall. Welldeveloped cortex of gravid proglottides forms oophore. Parasitic in shrews (Sorex) in Europe.

Type and only species: Gulyaevilepis tripartita (Żarnowski, 1955) comb. n.
E t y m o log y: The new genus is named after late Dr. Vladimir Dmitrievich Gulyaev in recognition of his contribution to cestodology.

Remarks. Gulyaevilepis resembles some genera of hymenolepidid cestodes (Ecrinolepis, Diorchilepis, Spasskylepis, Ditestolepis and Mathevolepis) that are parasitic in shrews of the family Soricidae in the possession of an unarmed scolex and serial strobilation. The new genus can be distinguished from the above-mentioned genera by the presence of one or two terminal sterile proglottides (with copulatory apparatus and without gonads) of each series in its strobila. Moreover, the new genus differs from Mathevolepis, Ecrinolepis, Spasskylepis and Diorchilepis in the shape of the ovary. The ovary of the above-mentioned genera is trilobed, whereas in Gulyaevilepis the ovary is bean-shaped or slightly bilobed (Gulyaev and Karpenko 1998, Gulyaev et al. 2004, Mel'nikova et al. 2004, 2005, Lykova et al. 2006).

Among all cestode genera with unarmed scolex and serial strobilation, only Diorchilepis, Ecrinolepis and Gulyaevilepis have a serial heteronomous organization of strobila, i.e. the strobila consists of several alternating series of hermaphroditic and male proglottides, which are released at the same time (see Gulyaev 1991), but only Gulyaevilepis has the whole copulatory part of the vagina covered with fine spines.

Furthermore, the new genus differs from Ecrinolepis and Diorchilepis, with which it shares an identical morphogenesis of the uterus (an initial horseshoe-shaped uterus transforms into sacciform not through the coalescence of its walls and branches, but by reducing the recess in the posterior wall of the uterus due to straightening of the wall), in the number of male proglottides and testes, and in the structure of the scolex (Kornienko 2001, Lykova et al. 2006). Only one proglottis in each series of Gulyaevolepis can be male, whereas cestodes of Ecrinolepis and Diorchilepis can have from three to fifty-five. Gulyaevilepis always have three testes in hermaphroditic and male proglottides, while Ecrinolepis has three testes in hermaphroditic proglottides and two testes in male proglottides, and Diorchilepis always has two testes (Lykova et al. 2006). The suckers on the scolex of the new genus are in bothrium-like depressions not far beyond the borders of the scolex as in Ecrinolepis and Diorchilepis.

Key to the genera of hymenolepidids with an unarmed scolex and serial strobilation parasitic in Soricidae.

1 Serial homonomous organization of the strobila, i.e. it consists of several series of hermaphroditic proglottides

- Serial heteronomous organization of the strobila, i.e.consists of several alternating series of male and hermaphroditic proglottides .................................. 4

2 Uterus initially sacciform ....................... Spasskylepis

- Uterus initially horseshoe-shaped ............................. 3 
A

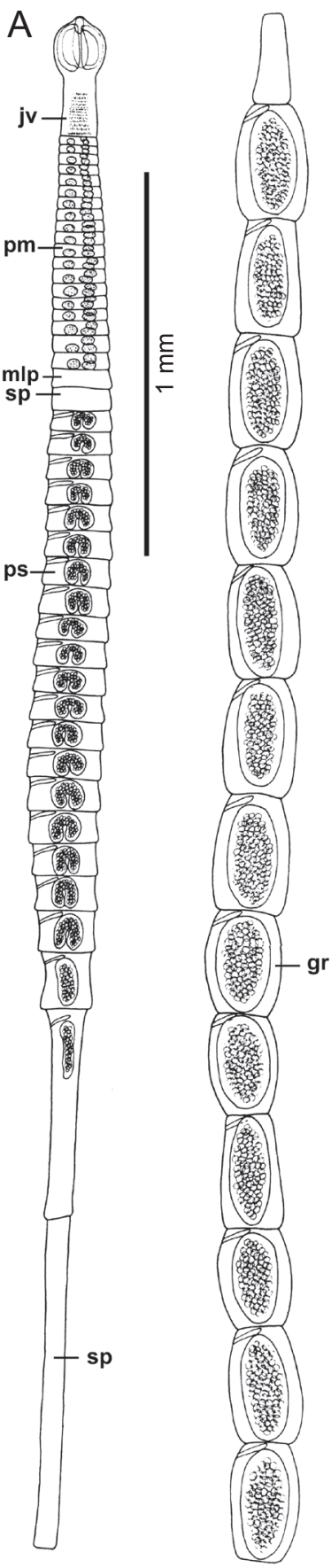

C
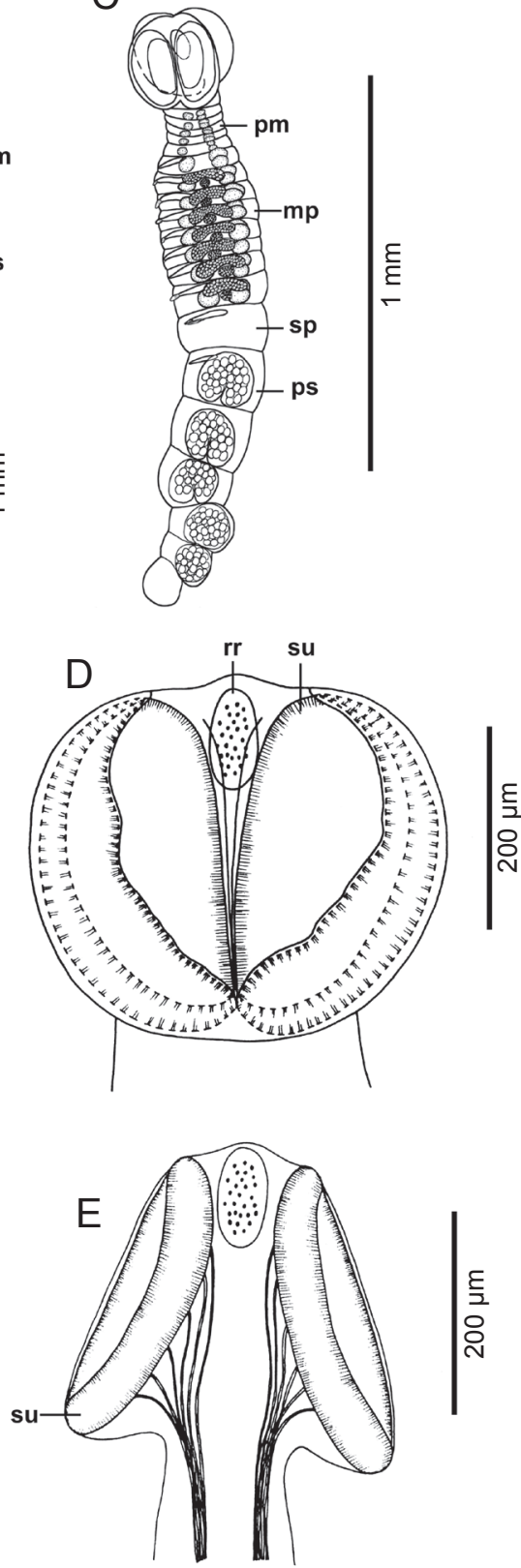

Fig. 1. Gulyaevilepis tripartita (Żarnowski, 1955) comb. n. A-C - general view of cestodes at various degree of development: $\mathbf{A}$ - gravid cestodes from Sorex satunini; $\mathbf{B}$ - gravid cestodes from Sorex araneus; $\mathbf{C}$ - cestode with last series of proglottides with horseshoe-shaped uterus from Sorex araneus (neotype); D, E - scolex: frontal and lateral view respectively. Abbreviations: gr - gravid proglottis; jv - juvenile proglottides; mlp - male proglottis; $\mathrm{mp}$ - mature proglottis; pm - pre-mature proglottis; ps - post-mature proglottis; rr - rudimentary rostellum; sp - sterile proglottis; su - sucker.

3 Uterus in gravid proglottides joins together and forms syncapsule; suckers inside of dorsal and ventral bothrium-like depressions of scolex; two or three testes per proglottis; ovary elongate, slightly bilobed Ditestolepis

- Uterus in gravid proglottides does not join together; gravid proglottides separated from strobila; suckers far beyond the borders of the scolex; three testes per proglottis; ovary trilobed Mathevolepis

4 Each series of strobila ends with one or two sterile proglottides Gulyaevilepis gen. $\mathrm{n}$. - Sterile proglottides not present in strobila 5 
5 Testes two; situated in one line in male and hermaphroditic proglottides Diorchilepis.

- Testes two in male proglottides; three testes situated in a triangle in hermaphroditic proglottides

Ecrinolepis

Gulyaevilepis tripartita (Żarnowski, 1955) comb. n.

Figs. 1-3

Syns.: Soricinia tripartita Żarnowski, 1955; Hymenolepis tripartita (Żarnowski, 1955) Vaucher, 1971; Ecrinolepis tripartita (Żarnowski, 1955) Gulyaev, 1991; Ditestolepis tripartita (Żarnowski, 1955) Czaplinski et Vaucher, 1994.

Redescription (based on six specimens from Sorex araneus, Lithuania, Latvia and Republic of Karelia, from S. satunini and S. volnuchini, north Caucasus). Small-sized worms, total length $1.3-8.6 \mathrm{~mm}(2.5 ; \mathrm{n}=6)$ (Fig. 1A-C). Strobilation serial with heteronomous organization. Strobila consists of several alternating series of hermaphroditic and male proglottides, $1-2(1 ; n=10)$ last proglottides of each series sterile. Only one male proglottis per series. Strobila with very rapid protandrous development consists of $17-71(29 ; n=6)$ proglottides. Each series containing 4-25 $(10 ; \mathrm{n}=10)$ proglottides at same developmental stage (Fig. 2). Strobila can contain 2-4 series of proglottides. If 2 series present, then 1 series with juvenile (primordia of testes) and second series with premature proglottides. Cestodes with 3 series consist of juvenile or pre-mature proglottides, mature or postmature proglottides with horseshoe-shaped uterus, and postmature proglottides with horseshoe-shaped uterus or pregravid proglottides (Fig. 1A-C). Fully developed strobila consists of 4 series of proglottides; latter 2 with pregravid and gravid proglottides. Formation and development of hermaphroditic, male and sterile proglottides in series are synchronous.

Male proglottis contains copulatory apparatus and three testes. Sterile proglottis only with copulatory apparatus (Fig. 2). Initially sterile proglottides wider than long, 76-127 × 180-251 (95 × 209; $\mathrm{n}=7)$, subsequently become long and narrow, 320-350 × 90-130 (327 × 109; $\mathrm{n}=7$ ) (Fig. 1A-C). Mature proglottides much wider than long, 33-89 × 152-248 $(58 \times 205 ; \mathrm{n}=11)$, acraspedote; first post-mature proglottides can be slightly craspedote. Gravid proglottides as long as wide, or longer than wide, $138-480 \times 132-290(295 \times 201 ; n=9)($ Fig. 1 A-C).

Genital pore regularly alternating, dextral, pre-equatorial genital atrium cylindrical, $8-16$ deep $(12 ; n=4)$. Two pairs of osmoregulatory canals. Ventral osmoregulatory canals with diameter 5-7 $(5 ; \mathrm{n}=8)$, dorsal with diameter $2-3(3 ; n=8)$. Transverse anastomoses not observed.

Scolex slightly compressed dorsoventrally, rounded, 191-260 wide $(228 ; n=6)$, clearly distinguished from neck 116-192 (155; $n=6)$ in width (Fig. 1D,E). Rostellar sac and rhynchus absent. Glandular sac-like rostellum ru-

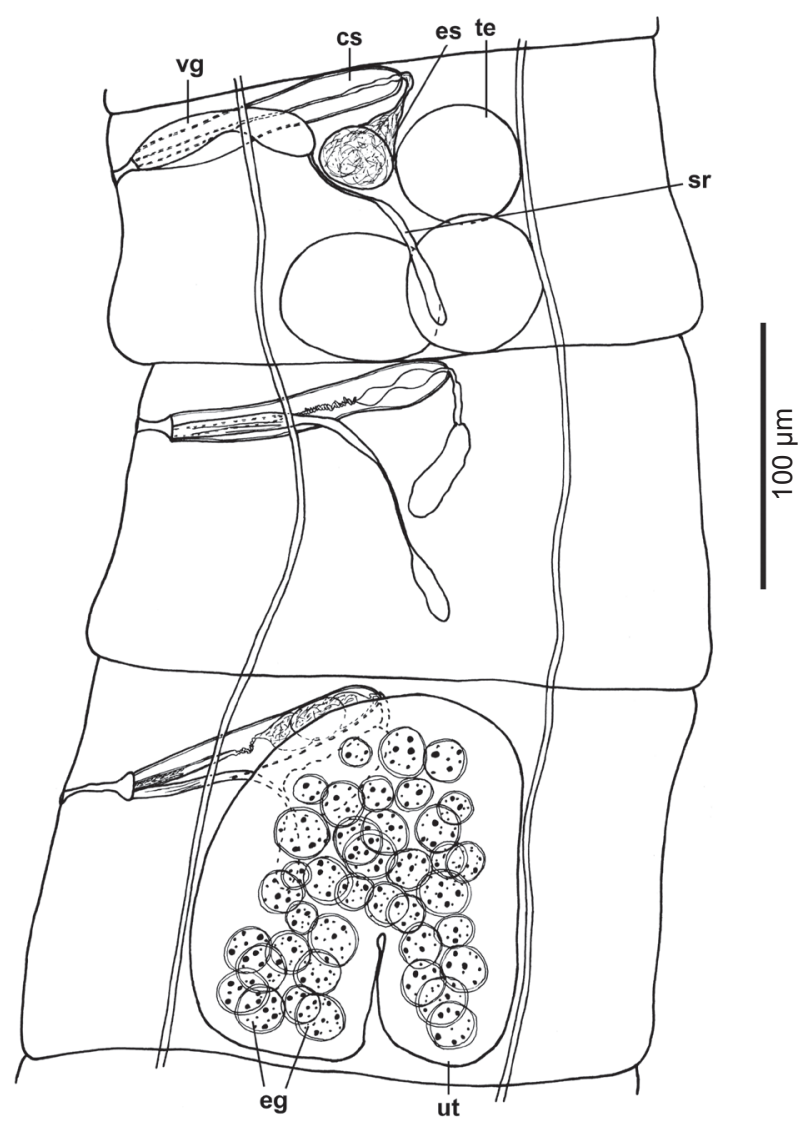

Fig. 2. Part of strobila of Gulyaevilepis tripartita (Żarnowski, $1955)$ comb. n. from Sorex araneus with sterile proglottis (in the middle). Abbreviations: cs - cirrus-sac; eg - eggs; es - external seminal vesicle; $\mathrm{sr}$ - seminal receptacle; te - testes; ut - uterus; $\operatorname{vg}$ - vagina.

dimentary, unarmed, 51-88 long $\times 29-48$ wide $(67 \times 38$; $\mathrm{n}=6$ ). Four oval, cup-shaped suckers inside of dorsal and ventral bothrium-like depressions of scolex, 146-204 $\times$ 85-128 $(172 \times 102 ; \mathrm{n}=11)$, with thin walls. Suckers adjoin to each other along mid-line (Fig. 1D).

Testes three, oval, 23-69 × 40-78 $(42 \times 54 ; \mathrm{n}=27)$, disposed in almost right-angled triangle in median field of proglottis, one poral and two antiporal (Fig. 3A). Cirrussac cigar-shaped, elongated, thin-walled, 80-132 × 16-20 $(101 \times 18 ; \mathrm{n}=13)$, reaching middle line of proglottis (Fig. 3A). Cirrus cylindrical, 31-50 (41; $n=11)$, broadened proximally, $10(\mathrm{n}=11)$ wide, on parabasal part covered with numerous, small, $2-2.7(2.4 ; \mathrm{n}=10)$ long, claw-shaped spines (Fig. 3G). Cirrus end $5(\mathrm{n}=11)$ wide, unarmed. Internal vas deferens makes few loops inside antiporal part of cirrus-sac, after filling of loops by sperm forms sack, $18-41 \times 10-16(27 \times 12, \mathrm{n}=10)$, which can occupy up to half of cirrus-sac length. External seminal vesicle elongate, $23-49 \times 12-23(37 \times 16, \mathrm{n}=7)$, bent, dorsal to cirrus-sac (Fig. 3C).

Ovary bean-shaped, compact or slightly bilobed, 23-41 $\times 67-131(32 \times 90 ; n=15)$, median or slightly aporal, an- 

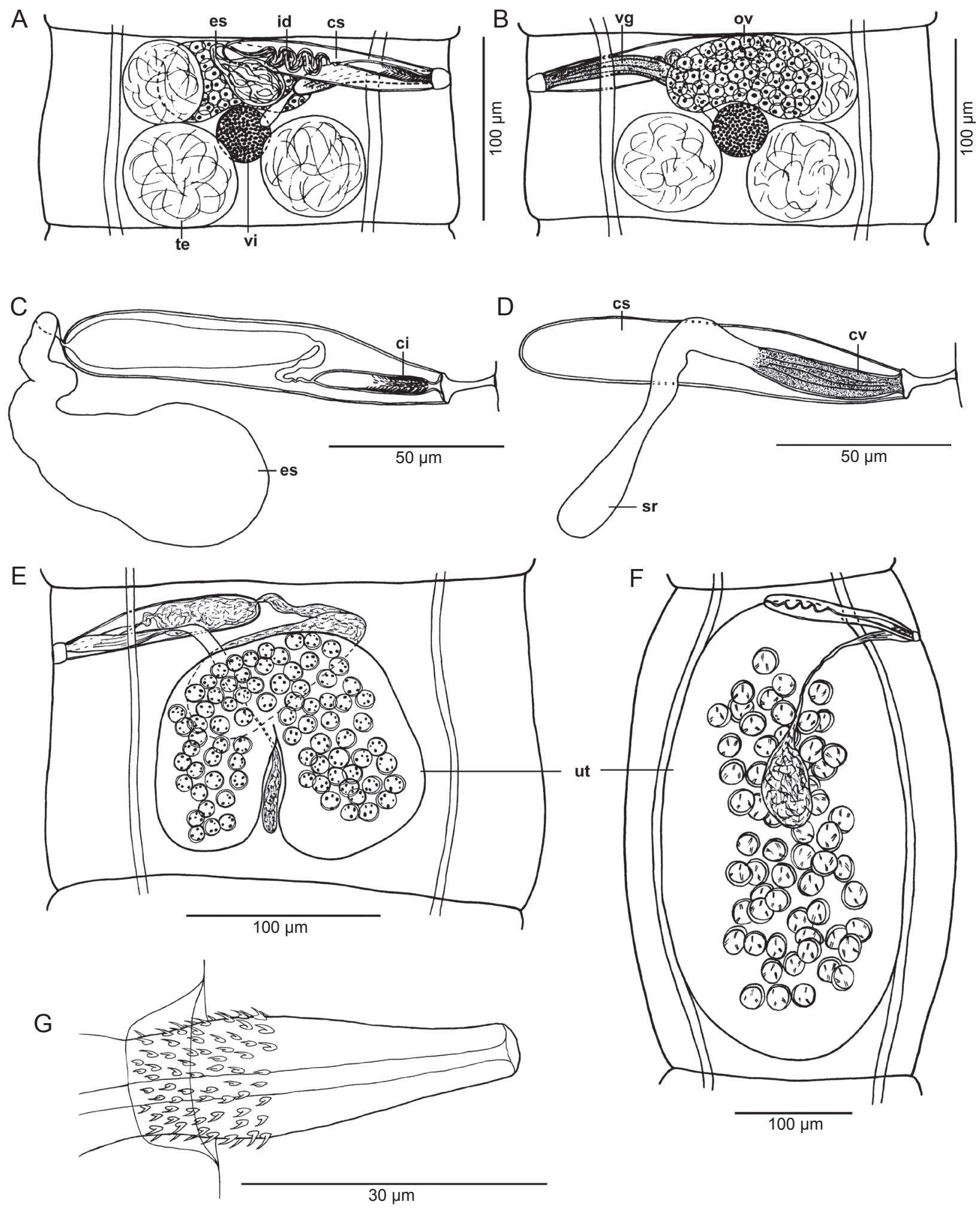

$100 \mu \mathrm{m}$

Fig. 3. Gulyaevilepis tripartita (Żarnowski, 1955) comb. n. from Sorex araneus. A, B-mature proglottides, dorsal and ventral view, respectively; C - cirrus-sac; D - vagina; copulatory part of vagina armed with numerous, fine spines; $\mathbf{E}$ - proglottis with horseshoeshaped uterus; F - gravid proglottis; G - evaginated cirrus. Abbreviations: ci - cirrus; cs - cirrus-sac; cv - copulatory part of vagina; es - external seminal vesicle; id - internal vas deferens; ov - ovary; $\mathrm{sr}$ - seminal receptacle; te - testes; ut - uterus; vg - vagina; vi - vitellarium. 
teroventral to testes (Fig. 3B). Vagina tubular, thin-walled, $52-71 \times 5-9(62 \times 6 ; \mathrm{n}=8)$, reaches mid-line of proglottis, runs parallel with, and ventral to, cirrus-sac and opens ventrally. Seminal receptacle small, thin-walled, difficult to observe in some proglottides. Copulatory part of vagina internally covered with numerous, fine spines (Fig. 3D). Vitellarium compact, rounded, 18-31 × 22-39 $(22 \times 32$; $\mathrm{n}=15$ ), ventral to testes, posterior to ovary (Fig. 3A,B).

Young uterus horseshoe-like (Fig. 3E), gravid uterus sac-like (Fig. 3F), occupying almost entire median field, does not cross osmoregulatory canals. Horseshoe-shaped uterus during maturation transforms to sacciform without coalescence of walls, but by reducing recess due straightening posterior wall of uterus. Uterus in gravid proglottides sac-like, oval, 111-396 × 84-189 $(200 \times 125 ; \mathrm{n}=10)$. Gravid proglottides detach from strobila one by one or in groups. Eggs oval, 18-24 × 15-23 $(21 \times 19 ; \mathrm{n}=10)$. Walls of separated proglottides forming oophore.

Type host: Sorex araneus Linnaeus.

Other hosts: Sorex caecutiens Laxmann; Sorex satunini Ognev; Sorex minutus Linnaeus; Sorex raddei Satunin; Sorex volnuchini Ognev.

Type locality: Surroundings of Pulawy, Lublin District, Poland (Żarnowski 1955).

Locality of ne otype: Surroundings of Navikai, Varena District, Lithuania, $\left(54^{\circ} 07^{\prime} 59^{\prime \prime} \mathrm{N} ; 2^{\circ} 01^{\prime} 05^{\prime \prime} \mathrm{E}\right)$.

Other localities: Western Central and Eastern EuropeBelarus, Bulgaria, Czech Republic, Finland, Latvia, Estonia, Lithuania, Norway, Poland, Russia (Republic of Komi - new geographical record, Caucasus, Arkhangelsk Oblast and Republic of Karelia), Sweden, Switzerland, Ukraine.

Site infection: Intestine.

Type material: Holotype is not known to exist and has been probably lost. The complete specimen from $S$. araneus from Lithuania, collected on 6 September 2009 (host field number 773), is designated as neotype and deposited in MNHG (MNHG-PLAT-83974). The neotype specimen and another cestode specimen belonging to the same species were mounted on one slide. Other specimens studied are deposited in the EKOI (HELMI 354, 1 spec. from S. araneus, Aizkraukle District, Latvia, collected on 8 February 2007; HELMI 132, Gomselga area, Republic of Karelia, Russia, collected on 16 October 2003) and ISEA (No. 18.35.1, 1 spec. from $S$. satunini, Nalchik area, north Caucasus, collected on 13 October 2001; No. 18.35.2, 1 spec. from S. volnuchini, Nalchik area, north Caucasus, collected on 14 October 2001; and No. 18.35.3, 1 spec. from S. araneus, Petrozavodsk area (Republic of Karelia), collected on 21 September 2010).

\section{DISCUSSION}

The cestodes of the hymenolepidid genera from shrews with an unarmed scolex and serial development of proglottides, i.e. Diorchilepis, Ditestolepis, Ecrinolepis, Mathevolepis and Spasskylepis, have a small and delicate strobila. This complicates collection and fixation of these cestodes; in addition, the development and structural peculiarities of representatives of these genera make it difficult to study their morphology.

After the original description of Soricinia tripartita by Żarnowski (1955), a more detailed study of the morphology of this species was provided by Vaucher (1971). He noted its great similarity with Ditestolepis diaphana, but placed it in the genus Hymenolepis, together with all other species of cestodes from European shrews. Gulyaev (1991) did not consider the genus Soricinia to be valid and placed S. tripartita in Ecrinolepis as Ecrinolepis tripartita (Żarnowski, 1955) Gulyaev, 1991.

In contrast, Soricinia was considered valid by Czaplinski and Vaucher (1994), but they excluded serial strobilation from the diagnosis of the genus. Since $S$. tripartita is similar in its gross morphology to $D$. diaphana, it was transferred to Ditestolepis by Vaucher (in Czaplinski and Vaucher 1994). However, this generic assignation is not accepted herein because some morphological features of G. tripartita differ significantly from those typical of Ditestolepis.

Gulyaevilepis differs from Ditestolepis in different development of the uterus, in the number of testes, in the possession of the copulatory part of the vagina armed with numerous, fine spines, and in serial heteronomous strobilation. Moreover, gravid proglottides of G. tripartita do not form a syncapsule as those of Ditestolepis do. In summary, morphological and molecular data (Haukisalmi et al. 2010) provide sufficient support to propose Gulyaevilepis as a new genus of the Hymenolepididae.

Acknowledgements. We are grateful to Valentina S. Anikanova and Sergey V. Bugmyrin for their help in the collecting of material from Karelia, and to Tomáš Scholz and anonymous reviewers for their valuable comments on this manuscript. We are especially grateful to Xenija A. Lykova for the drawings of cestode specimens. This study was partly funded by the Russian Fund for Fundamental Research (project Nos. 11-04-00870-a, 11-0400534-a and 13-04-10140-к).

\section{REFERENCES}

Binkiené R., Kontrimavichus V., Hoberg E. 2011: Overview of the cestode fauna of European shrews of the genus Sorex with comments on the fauna in Neomys and Crocidura and an exploration of historical processes in post-glacial Europe. Helminthologia 48: 207-228.

Czaplinski B., Vaucher C. 1994: Family Hymenolepididae Ariola, 1899. In: L.F. Khalil, A. Jones and R.A. Bray (Eds.), Keys to the Cestode Parasites of Vertebrates. CAB International, Wallingford, pp. 595-663.

Genov T. 1984: [Helminths of Insectivorous and Rodents in Bulgaria.] Publishing House of the Bulgarian Academy of Sciences, Sofia, 348 pp. (In Bulgarian.)

GulyaeV V.D. 1991: [Morphology and taxonomy of Ditestolepidini - cestodes (Cyclophyllidea) of shrews with the serial 
metameric structure of the strobila.] Zool. Zh. 70: 44-53. (In Russian.)

Gulyaev V.D., KarpenKo S.V. 1998: [Cestodes of the genus Mathevolepis (Cestoda: Cyclophyllidea, Hymenolepididae) from the common shrews of the Holarctic region.] Parazitologiya 32: 507-518. (In Russian.)

Gulyaev V.D., Lykova K.A., Mel'nikova Yu.A., Bibik E.V. 2004: [Validity of species Spasskylepis ovaluteri (Cestoda, Cyclophyllidea, Hymenolepididae) - parasite of shrews from Palearctic.] Zool. Zh. 83: 387-394. (In Russian.)

Haukisalmi V., Hardman L.M., Foronda P., Feliu C., Laakkonen J., Niemimaa J., Lehtonen J.T., Henttonen H. 2010: Systematic relationships of hymenolepidid cestodes of rodents and shrews inferred from sequences of $28 \mathrm{~S}$ ribosomal RNA. Zool. Scr. 39: 631-641.

Kornienko S.A. 2001: [Cestodes of shrews from North-Eastern Altai (taxonomy, systematic and ecology).] PhD thesis, Institute of Systematics and Ecology of Animals, Siberian Branch, Russian Academy of Science, Novosibirsk, 23 pp. (In Russian.)

Lykova K.A., Gulyaev V.D., Mel'nikova Yu.A., Karpenko S.V. 2006: [Diorchilepis is new genus of cestodes (Cyclophyllidea, Hymenolepididae, Ditestolepidini) and redescription of Diorchilepis ezoensis comb. $\mathrm{n}$. from shrews of Sakhalin Island and the Kuril Islands.] Zool. Zh. 85: 1506-1510. (In Russian.)

Received 27 May 2013
Mas-Coma S., Puchades M.T. 1991: A methodology for the morphoanatomic and systematic study of the species of the family Hymenolepididae Railliet et Henry, 1909 (Cestoda: Cyclophyllidea). Res. Rev. Parasitol. 51: 139-173.

Mel'nikova Yu.A., Lykova K.A., Gulyaev V.D. 2004: [Ecrinolepis kontrimavichusi sp. n. (Cyclophyllidea, Hymenolepididae) is a new cestode in shrews from the Far East southern Primorye.] Zool. Zh. 83: 1275-1279. (In Russian.)

Mel'nikova Yu.A., Lykova K.A., Gulyaev V.D. 2005: [Ecrinolepis orientales sp. n. (Cyclophyllidea, Hymenolepididae), a new species of cestodes from shrews of southern Primorye.] Zool. Zh. 84: 746-749. (In Russian.)

RYвICKA K. 1959: Tapeworms of forest micromammalians (Rodentia and insectivores) from Kampinos Wilderness. Acta Parasitol. Pol. 7: 46-55.

SPASSKY A.A. 1954: [Classification of hymenolepidids of mammals]. Trudy GELAN 7: 120-167. (In Russian.)

VAuCher C. 1971: Les cestodes parasites des Soricidae d'Europe. Etude anatomique revision taxonomique et biologie. Rev. Suisse Zool. 78: 1-113.

ŻARNOWSKI E. 1955: [Parasitic worms of forest micromammalians (Rodentia and Insectivora) of the enviroment of Pulawy (district Lublin). 1. Cestoda.] Acta Parasitol. Pol. 3: 279-368. (In Polish.)

Accepted 5 November 2013 